\title{
Anaesthesia and analgesia in laboratory adult zebrafish: a question of refinement
}

\section{Tânia Martins, Ana M. Valentim, Nuno Pereira, Luís M. Antunes}

Originally published in: Martins, T., Valentim, A. M., Pereira, N., \& Antunes, L. M. (2016). Anaesthesia and analgesia in laboratory adult zebrafish: a question of refinement. Laboratory animals, 50(6), 476488. (doi: 10.1177/0023677216670686).

\begin{abstract}
Anaesthesia is daily used in fish experimental procedures, however, the use of an inadequate anaesthetic protocol can compromise not only the animal's welfare but also results' reliability. The use of zebrafish (Danio rerio) in biomedical research increased in the last decades, highlighting the importance of appropriate anaesthetic regimes for this species. This article reviews the main anaesthetic agents and protocols used in laboratory adult zebrafish, and some analgesic methods that still need more research to be used in this species. In addition, it is proposed a systematized observation of signs to evaluate adult zebrafish welfare to reduce pain and distress.
\end{abstract}

\section{INTRODUCTION}

The use of zebrafish (Danio rerio) in biomedical research has increased. Indeed, the percentage of publications using zebrafish almost tripled in the last decade ${ }^{1,2}$ in several research areas. In biomedical research, the behavioural or physiological changes that occur when an animal is exposed to a stressful or painful event can lead to unreliable results. The use of anaesthetic, sedative, or analgesic drugs is essential for reducing stress and/or pain in fish since they are sentient animals capable of pain perception ${ }^{-5}$. Studies have demonstrated that fish show changes in normal behaviour and in physiological responses after being subjected to noxious stimuli, which may be ameliorated by the use of analgesics ${ }^{6-8}$. Despite these evidences, the discussion about pain perception in fish is still ongoing among researchers9. Nevertheless, there is an agreement regarding the importance of fish welfare and that efforts should be made to minimize painful and stressful conditions 9,10 .

Although the use of anaesthetics is important to assure zebrafish welfare, these drugs can also have side-effects ${ }^{11}$, being essential to establish an anaesthetic regime (doses, combinations) that suits each research procedure in order to minimise collateral effects. This review summarizes the anaesthetic and analgesic drugs that are used in laboratory adult zebrafish, anaesthesia protocols, anaesthesia depth, and recovery. Also, during all the experiment is of major importance to monitor zebrafish welfare, and for that, we propose a score sheet to monitor distress and pain. 


\section{ANAESTHESIA}

Anaesthesia and sedation (Table 1) are routinely used in husbandry, clinical procedures and research. Thus, it is important to understand the side-effects of these drugs and how it may affect project outcomes in research. Anaesthesia has been described to negatively affect cognitive functions or to cause neurotoxicity, however, these effects are dependent on individuals' age, regime of administration, dose, duration and type of anaesthesia ${ }^{12}$. These factors combined with a yet scarce knowledge regarding anaesthesia in fish, make it difficult to choose an appropriate anaesthetic protocol suitable for each procedure.

Anaesthesia in fish may be achieved by diluting the anaesthetics in the water (inhalation anaesthesia), which induces a general anaesthesia with the drug being absorbed mainly through the gills but also through the skin in few species $3,{ }^{13}, 14$. In fish, anaesthesia effects may vary depending on the administration route, $\mathrm{pH}$, temperature, salinity, oxygenation, nitrogenous compounds and other water conditions ${ }^{3}$. Furthermore, anaesthesia depth and recovery depends on its duration, anaesthetic concentration, animals' body weight and metabolism, gill surface, fish health status, strain, age, and on the different particularities of fish species $3,11,15$. Thus, anaesthesia trials with small numbers of fish, i.e. pilot studies, must be performed to determine the optimal dosage and exposure time prior to the establishment of protocols. In addition, proper training and supervision of fish anaesthesia are essential to avoid complications that can lead to death. Not only anaesthesia should be carefully monitored but also complete fish recovery ${ }^{2,16}$, which has been disregarded in the literature. 
Table 1. Anaesthesia stages in fish

\begin{tabular}{|c|c|c|c|}
\hline $\begin{array}{l}\text { Stage of } \\
\text { anaesthesia }\end{array}$ & Description & Physiological and behavioural signs & Clinical interest \\
\hline o & Normal & $\begin{array}{l}\text { Total equilibrium. } \\
\text { Normal muscle tone. } \\
\text { Normal reaction to visual and tactile stimuli. } \\
\text { Normal respiratory rate. }\end{array}$ & \\
\hline I & $\begin{array}{l}\text { Light } \\
\text { sedation }\end{array}$ & $\begin{array}{l}\text { Slight loss of reaction to visual and tactile } \\
\text { stimuli. }\end{array}$ & $\begin{array}{l}\text { Can reduce stress and } \\
\text { physical trauma during } \\
\text { transport }\end{array}$ \\
\hline II & $\begin{array}{l}\text { Deep } \\
\text { sedation }\end{array}$ & $\begin{array}{l}\text { Slight decrease in muscle tone. } \\
\text { No reaction to visual and light tactile stimuli. } \\
\text { Small decrease in respiratory rate. }\end{array}$ & $\begin{array}{l}\text { Appropriate stage for close } \\
\text { visual observation and for } \\
\text { minimal manipulation, } \\
\text { weighing and measuring. }\end{array}$ \\
\hline III & $\begin{array}{l}\text { Light } \\
\text { narcosis / } \\
\text { excitement } \\
\text { phase }\end{array}$ & $\begin{array}{l}\text { Partial loss of equilibrium/Weak responses to } \\
\text { postural changes. } \\
\text { Decrease in muscle tone. } \\
\text { Increased reaction to visual and tactile stimuli. } \\
\text { Respiratory rate increased and/or irregular. }\end{array}$ & $\begin{array}{l}\text { Higher risk of physical injury } \\
\text { or escape / jump from } \\
\text { container or aquarium }\end{array}$ \\
\hline IV & $\begin{array}{l}\text { Deep } \\
\text { narcosis }\end{array}$ & $\begin{array}{l}\text { Total loss of equilibrium/Lack of responses to } \\
\text { postural changes. } \\
\text { No reaction to minor visual and tactile stimuli. } \\
\text { Respiratory rate decreasing to almost normal. }\end{array}$ & $\begin{array}{l}\text { Good plane for external } \\
\text { sampling and blood } \\
\text { sampling. Avoid painful } \\
\text { procedures / analgesia may } \\
\text { not be present. Suitable for } \\
\text { imaging techniques }\end{array}$ \\
\hline V & $\begin{array}{l}\text { Light } \\
\text { anaesthesia }\end{array}$ & $\begin{array}{l}\text { Complete loss of muscle tone. } \\
\text { No reaction to painful stimuli. } \\
\text { Decrease in respiratory rate. } \\
\text { Decrease in heart rate. }\end{array}$ & $\begin{array}{l}\text { Minor surgical procedures: } \\
\text { fin biopsies and gill biopsies }\end{array}$ \\
\hline VI & $\begin{array}{l}\text { Surgical } \\
\text { anaesthesia }\end{array}$ & $\begin{array}{l}\text { Absence of reaction to massive stimulation. } \\
\text { Respiratory rate very low. } \\
\text { Slow heart rate. }\end{array}$ & Major surgical procedures \\
\hline VII & $\begin{array}{l}\text { Medullary } \\
\text { collapse/ } \\
\text { Overdose }\end{array}$ & $\begin{array}{l}\text { Flaccid muscle tone. } \\
\text { Apnea - absence of respiratory rate, which can } \\
\text { be followed in several minutes by cardiac arrest } \\
\text { if anaesthesia depth is not decreased. } \\
\text { Eventual death. }\end{array}$ & Appropriate for euthanasia \\
\hline
\end{tabular}




\section{ANAESTHETIC AGENTS USED IN FISH}

The ideal anaesthetic agent should (i) be easy to administer and effective at low dose or exposure; (ii) be able to induce sedation or anaesthesia in less than 3 min with a minimum of stress; (iii) provide immobilisation and effective analgesia during all the procedure; (iv) induce a quick recovery from the anaesthetic stage, within $5 \mathrm{~min}$, and (v) induce no or minimal changes in physiology and behaviour during or after anaesthesia15. Ideally, the anaesthetic should be affordable, easily available, practical to use, and safe to the operator.

A recent international survey showed that around $93 \%$ of the surveyed use MS-222 for zebrafish anaesthesia. The use of 2-phenoxyethanol, benzocaine, clove oil, isoeugenol, etomidate, and lidocaine was also referred ${ }^{19}$. Following, several anaesthetic agents are discussed.

\section{MS-222}

Tricaine methanesulfonate or MS-222, classified as a local anaesthetic, is the most used inhalant anaesthetic in fish. MS-222 is highly absorbed through the gills and is administrated by bath, inducing general anaesthesia. Overall it is a safe anaesthetic to fish2o, although there are some concerns regarding risks of overdose in deeper stages of anaesthesia and long duration procedures, mainly in small animals as zebrafish 2, 14, 20, 21. The anaesthetic solution of MS-222 should be buffered before use due to its acidic nature, which may cause aversion, epidermal and corneal lesions, and physiological alterations in the fish ${ }^{14,22,23}$. Also, MS-222 can be toxic to humans ${ }^{14,}{ }^{24}$.

\section{Clove oil}

Eugenol is the major constituent (70-90\% by weight) of clove oil extracted from the plant Syzygium aromaticum. Clove oil and eugenol are used as inhalant anaesthetic, and must be mixed with ethanol to be soluble in the water bath. They showed rapid induction times and consistent anaesthesia, however, fish recovery takes longer than with MS-222 3. Clove oil is efficient at a range of temperatures, easily available, and relatively inexpensive 3 . Aqui-S is a similar product available in the market constituted by isoeugenol, another compound of clove oil, which is soluble in water. Both have been suitable for harvesting and fish transportation 3,15. In general, there are equivocal evidence of carcinogenic activity of eugenol and isoeugenol, while methyleugenol, other clove oil constituent, is carcinogenic to rodents 25 .

\section{Metomidate and Etomidate}

Metomidate and etomidate are nonbarbiturate hypnotic drugs, and both are used as inhalant anaesthetics in a water bath in fish. These agents induce quick anaesthesia induction and recovery but they should only be used for minor procedures, as they do not induce a surgical anaesthetic stage or analgesia 3, 15. Also, they alter fish physiology by suppressing cortisol production ${ }^{11,15}$. 


\section{Lidocaine}

Lidocaine hydrochloride, a local anaesthetic and analgesic15, is used as an immersion anaesthetic in fish. It induces anaesthesia within $1 \mathrm{~min}$ and the recovery is also rapid, taking about three to four times the induction period 15. A high dose of lidocaine seems promising as an anaesthetic agent for surgical procedures but has a low margin of safety in zebrafish ${ }^{20}$. Thus, the addition of another agent, as propofol, may potentiate this effect and reduce the dosage ${ }^{2}$. Moreover, perioperative analgesia with lidocaine seemed to improve zebrafish welfare ${ }^{26}$.

\section{Propofol}

Propofol is a sedative-hypnotic anaesthetic drug used for the induction and maintenance of general anaesthesia ${ }^{27}$. Propofol can be injected or used in an anaesthetic bath. It is rapidly metabolized, thus, lacking cumulative effects. Although propofol is highly lipophilic, it can induce anaesthesia in a rapid and smooth way. Moreover, the recovery from anaesthesia is also quick and complete ${ }^{2,28}$. Although the preliminary results seem promising ${ }^{2}$ it may not be fully soluble in the water and more research is needed.

\section{Ketamine}

Ketamine is an injectable agent often used in mammals and induces a dissociative anaesthesia with some analgesia ${ }^{29,30}$. In fish, it can be injected or used in an anaesthetic bath. The use of ketamine in fish depends largely on the species, since it could cause incomplete anaesthesia, apnoea, prolonged recovery and excitement in Salmonid species 3 . Ketamine revealed to be neurotoxic to zebrafish larvae ${ }^{31,32}$, and to interfere with the development of embryos 33 .

\section{Isoflurane}

Isoflurane is a hypnotic volatile drug routinely used in mammals anaesthesia. Studies evaluating volatiles in fishes are scarce, since the anaesthetic depth is difficult to control, causing overdose 3,20 . Furthermore, anaesthetic preparation and anaesthesia should be conducted in a chemical fume hood for scavenging waste gas, reducing the risk to the operator. These characteristics and the observed clinical effects turn volatile anaesthetics less practicable in fish anaesthesia 3,20 .

\section{ANAESTHESIA IN LABORATORY ADULT ZEBRAFISH}

Laboratory zebrafish has emerged as a powerful vertebrate model system in research ${ }^{1,34}$. Despite this interest, the research on welfare and refinement of procedures in this species are scarce. Pain and unexpected mortality due to incorrect anaesthesia in zebrafish can constitute a serious animal welfare issue, which increases data variability, carrying an important scientific and economical cost in daily research.

Table 2 provides a summary of the main anaesthetic agents used in adult zebrafish, and their effects. Immersion is the most common method used, especially in small fish as zebrafish, where other 
invasive routes are impractical. Protocols for fish anaesthesia usually include only one anaesthetic agent instead of a combination, however, some studies have demonstrated that the mixture of two types of anaesthetics can result in a safer and more effective anaesthesia 2, 21

\section{西}




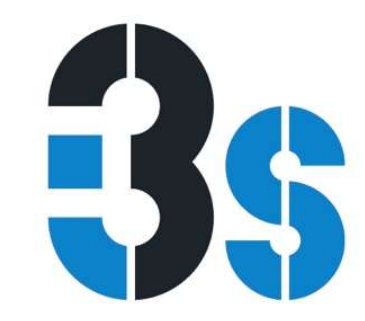

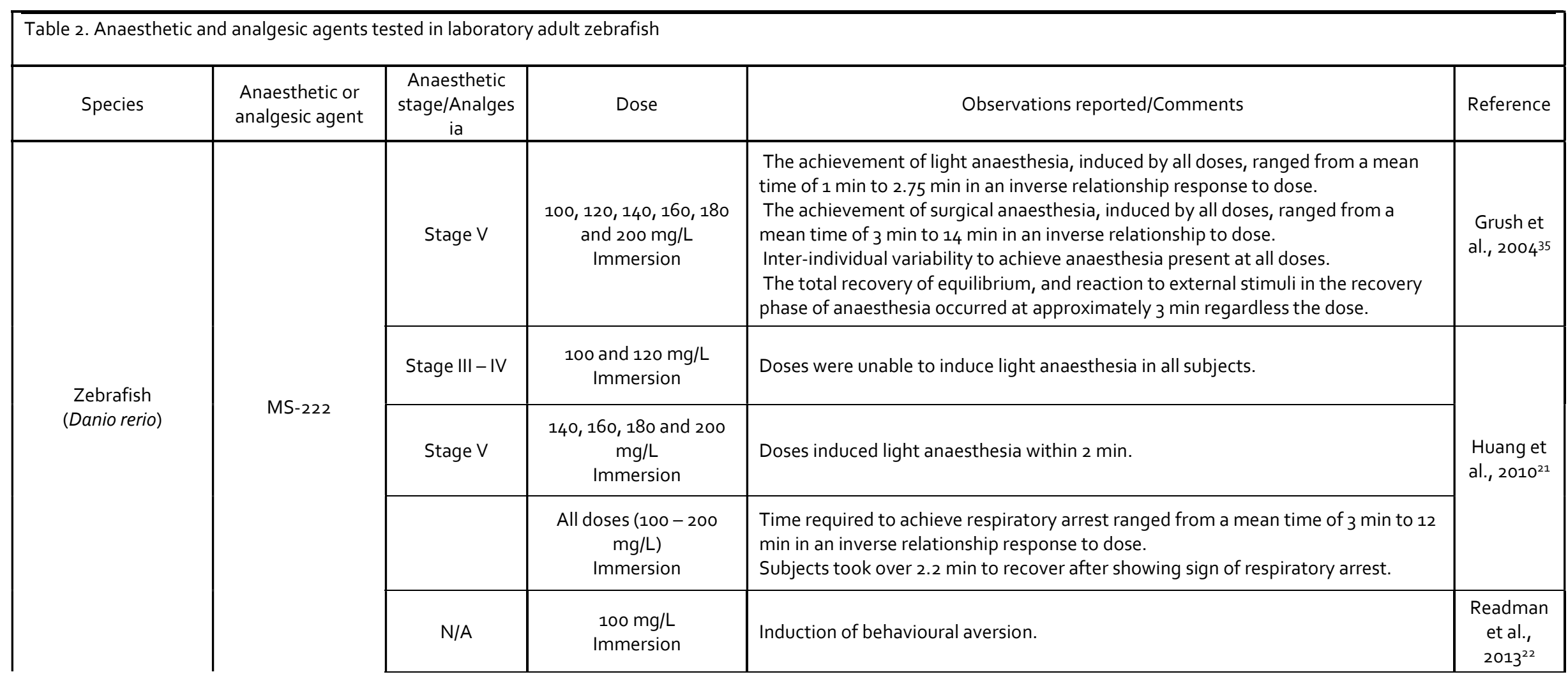



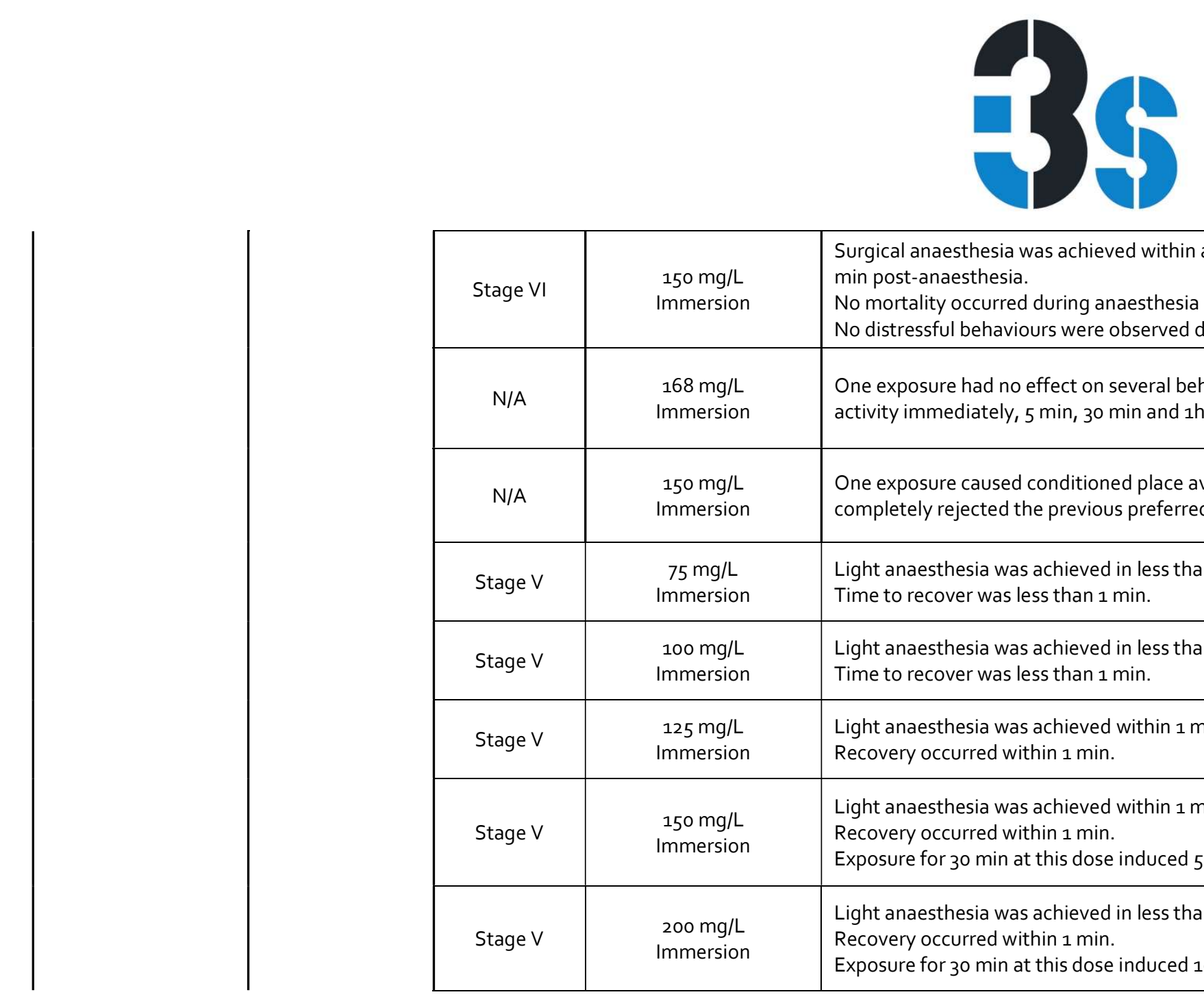

\begin{tabular}{|c|c|c|}
\hline Stage VI & $\begin{array}{l}150 \mathrm{mg} / \mathrm{L} \\
\text { Immersion }\end{array}$ & $\begin{array}{l}\text { Surgical anaesthesia was achieved within a mean time of } 4.2 \text { min and recovery } 2.3 \\
\text { min post-anaesthesia. } \\
\text { No mortality occurred during anaesthesia or postanaesthetic period. } \\
\text { No distressful behaviours were observed during induction or recovery. }\end{array}$ \\
\hline $\mathrm{N} / \mathrm{A}$ & $\begin{array}{l}168 \mathrm{mg} / \mathrm{L} \\
\text { Immersion }\end{array}$ & $\begin{array}{l}\text { One exposure had no effect on several behavioural parameters of anxiety and } \\
\text { activity immediately, } 5 \mathrm{~min}, 30 \mathrm{~min} \text { and } 1 \mathrm{~h} \text { after recovery. }\end{array}$ \\
\hline $\mathrm{N} / \mathrm{A}$ & $\begin{array}{l}150 \mathrm{mg} / \mathrm{L} \\
\text { Immersion }\end{array}$ & $\begin{array}{l}\text { One exposure caused conditioned place aversion and } 53 \% \text { of the subjects } \\
\text { completely rejected the previous preferred side of the tank. }\end{array}$ \\
\hline Stage V & $\begin{array}{l}75 \mathrm{mg} / \mathrm{L} \\
\text { Immersion }\end{array}$ & $\begin{array}{l}\text { Light anaesthesia was achieved in less than } 2 \text { min. } \\
\text { Time to recover was less than } 1 \text { min. }\end{array}$ \\
\hline Stage V & $\begin{array}{l}100 \mathrm{mg} / \mathrm{L} \\
\text { Immersion }\end{array}$ & $\begin{array}{l}\text { Light anaesthesia was achieved in less than } 2 \text { min. } \\
\text { Time to recover was less than } 1 \text { min. }\end{array}$ \\
\hline Stage V & $\begin{array}{l}125 \mathrm{mg} / \mathrm{L} \\
\text { Immersion }\end{array}$ & $\begin{array}{l}\text { Light anaesthesia was achieved within } 1 \text { min. } \\
\text { Recovery occurred within } 1 \text { min. }\end{array}$ \\
\hline Stage V & $\begin{array}{l}150 \mathrm{mg} / \mathrm{L} \\
\text { Immersion }\end{array}$ & $\begin{array}{l}\text { Light anaesthesia was achieved within } 1 \text { min. } \\
\text { Recovery occurred within } 1 \text { min. } \\
\text { Exposure for } 30 \text { min at this dose induced } 50 \% \text { of mortality. }\end{array}$ \\
\hline Stage V & $\begin{array}{l}200 \mathrm{mg} / \mathrm{L} \\
\text { Immersion }\end{array}$ & $\begin{array}{l}\text { Light anaesthesia was achieved in less than } 1 \mathrm{~min} \text {. } \\
\text { Recovery occurred within } 1 \mathrm{~min} \text {. } \\
\text { Exposure for } 30 \mathrm{~min} \text { at this dose induced } 100 \% \text { of mortality. }\end{array}$ \\
\hline
\end{tabular}

Collymore et al., $2014^{20}$

Nordgree $n$ et al., $2014^{16}$

Wong et al., $2014^{36}$

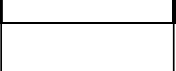

Chambel et al., $2015^{37}$ 


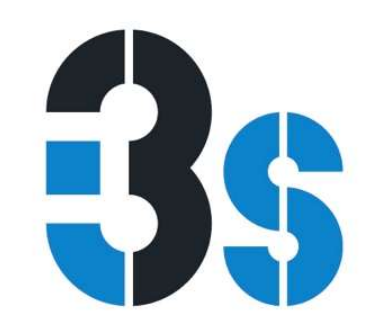

\begin{tabular}{|c|c|c|c|c|c|}
\hline & & Stage V & $\begin{array}{l}250 \mathrm{mg} / \mathrm{L} \\
\text { Immersion }\end{array}$ & $\begin{array}{l}\text { Light anaesthesia was achieved in less than } 1 \mathrm{~min} \text {. } \\
\text { Recovery occurred within } 1 \mathrm{~min} \text {. } \\
\text { Exposure for } 30 \mathrm{~min} \text { at this dose induced } 100 \% \text { of mortality. }\end{array}$ & \\
\hline & & Stage VI & $\begin{array}{l}100 \mathrm{mg} / \mathrm{L} \\
\text { Immersion }\end{array}$ & No mortality occurred during anaesthesia or postanaesthetic period. & $\begin{array}{l}\text { Valentim } \\
\text { et al., } \\
2016^{2}\end{array}$ \\
\hline \multirow[b]{2}{*}{$\begin{array}{l}\text { Zebrafish } \\
\text { (Danio rerio) }\end{array}$} & \multirow[b]{2}{*}{ Clove oil } & $\mathrm{N} / \mathrm{A}$ & $\begin{array}{l}55 \mathrm{mg} / \mathrm{L} \\
\text { Immersion }\end{array}$ & $\begin{array}{l}\text { One exposure caused some conditioned place aversion and only } 19 \% \text { of the } \\
\text { subjects completely rejected the previous preferred side. }\end{array}$ & $\begin{array}{l}\text { Wong et } \\
\text { al., } 2014^{36}\end{array}$ \\
\hline & & Stage V & $\begin{array}{l}60,80,100,120 \text { and } \\
140 \mathrm{mg} / \mathrm{L} \\
\text { Immersion }\end{array}$ & $\begin{array}{l}\text { The achievement of light anaesthesia, induced by all doses, ranged from a mean } \\
\text { time of } 0.5 \text { min to } 1 \text { min in an inverse relationship response to dose. } \\
\text { The achievement of surgical anaesthesia, induced by all doses, ranged from a mean } \\
\text { time of } 2.5 \text { min to } 8.5 \text { min in a negative exponential response to dose. } \\
\text { The total recovery of equilibrium after anaesthesia occurred at approximately } 5 \\
\text { min regardless of eugenol dose. } \\
\text { The reaction to external stimuli in the recovery phase of anaesthesia occurred at } \\
\text { approximately } 8 \mathrm{~min} \text {, regardless of eugenol dose. }\end{array}$ & $\begin{array}{l}\text { Grush et } \\
\text { al., } 2004^{35}\end{array}$ \\
\hline \multirow[b]{2}{*}{$\begin{array}{c}\text { Zebrafish } \\
\text { (Danio rerio) }\end{array}$} & \multirow[b]{2}{*}{$\begin{array}{l}\text { Metomidate } \\
\text { hydrochloride }\end{array}$} & Stage I & $\begin{array}{l}2 \text { and } 4 \mathrm{mg} / \mathrm{L} \\
\text { Immersion }\end{array}$ & The time to recover from anaesthesia ranged from $2.8 \mathrm{~min}$ to $5.2 \mathrm{~min}$. & \multirow[b]{2}{*}{$\begin{array}{l}\text { Collymore } \\
\text { et al., } \\
2014^{20}\end{array}$} \\
\hline & & Stage IV & $\begin{array}{l}\text { 6, } 8 \text { and } 10 \mathrm{mg} / \mathrm{L} \\
\text { Immersion }\end{array}$ & $\begin{array}{l}\text { Light anaesthesia occurred between } 2.3 \mathrm{~min} \text { and } 4.3 \mathrm{~min} \text {. } \\
\text { No surgical anaesthetic plane was achieved during the } 10 \mathrm{~min} \text { of exposure. } \\
\text { The time to recovery from anaesthesia ranged from } 5.6 \mathrm{~min} \text { to } 10.4 \mathrm{~min} \text { regardless } \\
\text { of the dose. } \\
\text { No distressful behaviours observed during anaesthesia. } \\
\text { No mortality during or after anaesthesia. }\end{array}$ & \\
\hline
\end{tabular}




\section{5}

\begin{tabular}{|c|c|c|c|c|c|}
\hline & & N/A & $\begin{array}{l}13.5 \mathrm{mg} / \mathrm{L} \\
\text { Immersion }\end{array}$ & $\begin{array}{l}\text { One exposure caused some conditioned place aversion and only } 11 \% \text { of the } \\
\text { subjects completely rejected the previous preferred side. }\end{array}$ & $\begin{array}{l}\text { Wong et } \\
\text { al., } 2014^{36}\end{array}$ \\
\hline \multirow{6}{*}{$\begin{array}{l}\text { Zebrafish } \\
\text { (Danio rerio) }\end{array}$} & \multirow{6}{*}{ Etomidate } & Stage IV & $\begin{array}{l}4 \text { to } 10 \mathrm{mg} / \mathrm{L} \\
\text { Immersion }\end{array}$ & $\begin{array}{l}\text { Induction of light anaesthesia was achieved for doses of } 4 \mathrm{mg} / \mathrm{L} \text { and higher, and } \\
\text { occurred in less than } 1 \mathrm{~min} \text {. } \\
\text { The time to recovery varied from around } 25 \mathrm{~min} \text { for } 4 \mathrm{mg} / \mathrm{L} \text { to } 60 \mathrm{~min} \text { for the } \\
\text { highest dose. }\end{array}$ & \multirow{5}{*}{$\begin{array}{l}\text { Amend et } \\
\text { al., } 1982^{38}\end{array}$} \\
\hline & & Stage IV & $\begin{array}{l}8 \text { to } 10 \mathrm{mg} / \mathrm{L} \\
\text { Immersion }\end{array}$ & Doses higher than $8 \mathrm{mg} / \mathrm{L}$ induced mortality. & \\
\hline & & $\mathrm{N} / \mathrm{A}$ & $\begin{array}{l}3 \mathrm{mg} / \mathrm{L} \\
\text { Immersion }\end{array}$ & $\begin{array}{l}\text { Exposure for more than } 10 \mathrm{~min} \text { and } 20 \text { min showed } 5 \% \text { and } 20 \% \text { of mortality, } \\
\text { respectively. }\end{array}$ & \\
\hline & & $\mathrm{N} / \mathrm{A}$ & $\begin{array}{l}9 \mathrm{mg} / \mathrm{L} \\
\text { Immersion }\end{array}$ & Exposure for $120 \mathrm{~s}$ on three consecutive days induced $30 \%$ of mortality. & \\
\hline & & $\mathrm{N} / \mathrm{A}$ & $\begin{array}{l}15 \mathrm{mg} / \mathrm{L} \\
\text { Immersion }\end{array}$ & Exposure for $120 \mathrm{~s}$ on three consecutive days induced $95 \%$ of mortality. & \\
\hline & & N/A & $\begin{array}{l}2 \mathrm{mg} / \mathrm{L} \\
\text { Immersion }\end{array}$ & No behavioural evidence of aversion was observed in the subjects exposed. & $\begin{array}{l}\text { Readman } \\
\text { et al., } \\
2013^{22}\end{array}$ \\
\hline \multirow[t]{2}{*}{$\begin{array}{l}\text { Zebrafish } \\
\text { (Danio rerio) }\end{array}$} & \multirow[t]{2}{*}{$\begin{array}{l}\text { Lidocaine } \\
\text { hydrochloride }\end{array}$} & N/A & $\begin{array}{l}100 \mathrm{mg} / \mathrm{L} \\
\text { Immersion }\end{array}$ & Induction of behavioural aversion. & $\begin{array}{c}\text { Readman } \\
\text { et al., } \\
2013^{22} \\
\end{array}$ \\
\hline & & Stage I & $\begin{array}{l}300 \mathrm{mg} / \mathrm{L} \\
\text { Immersion }\end{array}$ & $\begin{array}{l}\text { Induction of light sedation that occurred within a mean time of } 5.4 \text { min with a great } \\
\text { variability. } \\
\text { The recovery from anaesthesia occurred at a mean time of } 3.4 \text { min with a great } \\
\text { variability. } \\
\text { No mortality occurred during anaesthesia or postanaesthetic period. }\end{array}$ & $\begin{array}{l}\text { Collymore } \\
\text { et al., } \\
2014^{20}\end{array}$ \\
\hline
\end{tabular}




\section{5}

\begin{tabular}{|c|c|c|c|c|c|}
\hline & & Stage VI & $\begin{array}{l}325 \mathrm{mg} / \mathrm{L} \\
\text { Immersion }\end{array}$ & $\begin{array}{l}\text { Induction of surgical anaesthesia at a mean time of } 0.85 \mathrm{~min} \text { with a great } \\
\text { variability. } \\
\text { The recovery from anaesthesia occurred at a mean time of } 5.8 \mathrm{~min} \text { with a great } \\
\text { variability. } \\
\text { No mortality occurred during anaesthesia or postanaesthetic period. }\end{array}$ & \\
\hline & & Stage VI/ VII & $\begin{array}{l}350 \mathrm{mg} / \mathrm{L} \\
\text { Immersion }\end{array}$ & $\begin{array}{l}\text { Induction of surgical anaesthesia at a mean time of } 1.7 \mathrm{~min} \text {, and some subjects } \\
\text { experienced Stage VII - Medullary Collapse/Overdose. } \\
\text { The recovery from anaesthesia occurred at a mean time of } 1.9 \text { min with a great } \\
\text { variability. } \\
30 \% \text { mortality observed during anaesthesia. }\end{array}$ & \\
\hline & & Analgesic & $\begin{array}{l}0.1-2 \mathrm{mg} / \mathrm{kg} \\
(\mathrm{IM})\end{array}$ & $\begin{array}{l}\text { Analgesic drug. } \\
\text { No side effects observed. } \\
\text { Very efficient at } 1 \mathrm{mg} / \mathrm{kg} \text {. }\end{array}$ & $\begin{array}{l}\text { Sneddon, } \\
2012^{11}\end{array}$ \\
\hline & & Analgesic & $\begin{array}{l}2-5 \mathrm{mg} / \mathrm{L} \\
\text { Immersion }\end{array}$ & $\begin{array}{l}\text { Pre and post-surgical administration for tail fin clipping. } \\
\text { Reduction of pain-related behaviours. }\end{array}$ & $\begin{array}{c}\text { Schroeder } \\
2016^{26}\end{array}$ \\
\hline \multirow{2}{*}{$\begin{array}{c}\text { Zebrafish } \\
\text { (Danio rerio) }\end{array}$} & \multirow{2}{*}{ Propofol } & Stage V & $\begin{array}{l}2.5 \mathrm{mg} / \mathrm{L} \\
\text { Immersion }\end{array}$ & $\begin{array}{l}\text { The dose induced light anaesthesia in } 93.4 \% \text { of the subjects but was unable to } \\
\text { induce analgesia in } 40 \% \text { of the subjects. } \\
\text { This dose showed an occurrence of } 33 \% \text { mortality. }\end{array}$ & \multirow{2}{*}{$\begin{array}{l}\text { Valentim } \\
\text { et al., } \\
2016^{2}\end{array}$} \\
\hline & & Stage V & $\begin{array}{l}5 \text { and } 7.5 \mathrm{mg} / \mathrm{L} \\
\text { Immersion }\end{array}$ & $\begin{array}{l}\text { Both doses induced light anaesthesia but were unable to induce analgesia in } 36 \% \\
\text { and } 18 \% \text { of the subjects, respectively. } \\
\text { Both doses showed an occurrence of } 9 \% \text { mortality. }\end{array}$ & \\
\hline $\begin{array}{l}\text { Zebrafish } \\
\text { (Danio rerio) }\end{array}$ & $\begin{array}{l}\text { Propofol }(P) \\
\text { combined with } \\
\text { Lidocaine }(L)\end{array}$ & Stage VI & $\begin{array}{l}2.5 \mathrm{mg} / \mathrm{L}(\mathrm{P})+50 \\
\mathrm{mg} / \mathrm{L}(\mathrm{L}) i \\
\text { Immersion }\end{array}$ & No mortality occurred during anaesthesia or postanaesthetic period. & $\begin{array}{l}\text { Valentim } \\
\text { et al., } \\
2016^{2}\end{array}$ \\
\hline
\end{tabular}




\section{5}

\begin{tabular}{|c|c|c|c|c|c|}
\hline & & Stage VI & $\begin{array}{c}2.5 \mathrm{mg} / \mathrm{L}(\mathrm{P})+100 \\
\mathrm{mg} / \mathrm{L}(\mathrm{L}) ; \\
\text { Immersion } \\
\end{array}$ & Occurrence of $23 \%$ mortality. & \\
\hline & & Stage VI & $\begin{array}{c}2.5 \mathrm{mg} / \mathrm{L}(\mathrm{P})+150 \\
\mathrm{mg} / \mathrm{L}(\mathrm{L}) \\
\text { Immersion }\end{array}$ & Occurrence of $9 \%$ mortality. & \\
\hline \multirow[t]{2}{*}{$\begin{array}{l}\text { Zebrafish } \\
\text { (Danio rerio) }\end{array}$} & \multirow[t]{2}{*}{ Ketamine } & N/A & $\begin{array}{l}2000 \mathrm{mg} / \mathrm{L} \\
\text { (acute exposure during } \\
5 \text { min and chronic } \\
\text { exposure for } 5 \\
\text { consecutive days) } \\
\text { Immersion }\end{array}$ & $\begin{array}{l}\text { Sub-anaesthetic dose produced behavioural abnormalities such as increased } \\
\text { circling behaviour, decreased gill movement (ventilatory response to hypoxia), and } \\
\text { decreased stress response to hypoxia (body pulses). } \\
\text { The repeated administration of ketamine did not cause tolerance or sensitization } \\
\text { to specific drug effects. }\end{array}$ & \multirow[t]{2}{*}{$\begin{array}{l}\text { Zakhary } \\
\text { et al., } \\
2011^{39}\end{array}$} \\
\hline & & $\begin{array}{l}\text { Stage IV } \\
\text { (at least) }\end{array}$ & $\begin{array}{l}8000 \mathrm{mg} / \mathrm{L} \\
\text { Immersion }\end{array}$ & Physiological anaesthetic dose inducing a deep level of unconsciousness. & \\
\hline $\begin{array}{l}\text { Zebrafish } \\
\text { (Danio rerio) }\end{array}$ & Isoflurane & Stage III & $\begin{array}{l}0.5 \mathrm{~mL} / \mathrm{L} \\
\text { Immersion }\end{array}$ & $\begin{array}{l}\text { Distressful behaviours were observed (twitching, erratic swimming, and piping). } \\
\text { Signs of disorientation, difficulty maintaining buoyancy, rolling, and swimming } \\
\text { upside down also occurred. } \\
\text { Recovery from anaesthesia within a mean time of } 4.2 \text { min. } \\
30 \% \text { mortality during anaesthesia and } 1 \text { day post-anaesthesia. }\end{array}$ & $\begin{array}{l}\text { Collymore } \\
\text { et al., } \\
2014^{20}\end{array}$ \\
\hline $\begin{array}{l}\text { Zebrafish } \\
\text { (Danio rerio) }\end{array}$ & $\begin{array}{l}\text { Isoflurane (I) } \\
\text { combined with } \\
\text { MS-222 (M) }\end{array}$ & $\begin{array}{l}\text { Stage III-IV; } \\
\text { Stage V } \\
(10-20 \%)\end{array}$ & $\begin{array}{c}50 \mathrm{mg} / \mathrm{L}(\mathrm{I})+50 \mathrm{mg} / \mathrm{L}(\mathrm{M}) \\
\text { Immersion }\end{array}$ & Light anaesthesia was induced by this dose in only $10 \%-20 \%$ of the subjects. & $\begin{array}{l}\text { Huang et } \\
\text { al., } 2010^{21}\end{array}$ \\
\hline
\end{tabular}




\section{$3 s$}

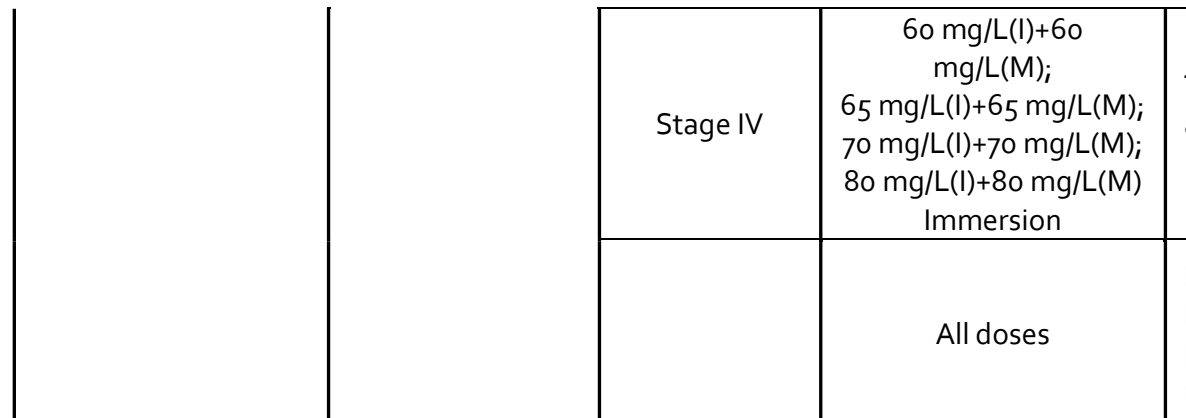

The combination doses between $60+60 \mathrm{mg} / \mathrm{L}$ and $80+80 \mathrm{mg} / \mathrm{L}$ induced light anaesthesia within $1.5 \mathrm{~min}$.

Regarding all doses, time required to achieve respiratory arrest ranged from a mean time of $6 \mathrm{~min}$ to $55 \mathrm{~min}$ in a negative exponential response to dose.

For all the combined doses the subjects recover within 2 min after showing sign of N/A - not applicable/not evaluated;

All anaesthetic agents were administered by immersion, with exceptions: IM - intramuscular injection

*(Paul Schroeder, personal communication, July 19, 2016) 


\section{MONITORING ZEBRAFISH WELFARE}

In addition to the importance of a good anaesthetic protocol to ensure fish welfare during experimental procedures, animals should also be monitored for distress, discomfort and pain during all the experimental protocol and maintenance. Fish have demonstrated to react consistently to noxious chemical stimuli and present reliable phenotypes of stress, fear, and anxiety 40, 41. Thus, the use of analgesic drugs in fish during and after painful experimental procedures should be considered, especially due to the fact that not all anaesthetic agents available for fish have proved to have adequate analgesic properties 3 . The information concerning the use of analgesics in zebrafish is extremely scarce (Table 2). Furthermore, the available analgesics tested in fish are administered intramuscularly and/or by the intraperitoneal route ${ }^{11}$, which make it difficult to perform in small fish, such as zebrafish, or in a large number of animals ${ }^{26}$. Lidocaine has recently been described as a promising analgesic for zebrafish ${ }^{26}$, which is an important step in the development of analgesic protocols to be administered in the water bath.

In Table 3 we suggest a score sheet to monitor the signs of distress and pain in adult zebrafish. This table is an initial proposal of a score sheet to monitor zebrafish welfare, and, as such, it should be further investigated for each individual protocol and genetic background. 


\begin{tabular}{|c|c|c|}
\hline & Score & \\
\hline \multicolumn{3}{|l|}{ Physical appearance* } \\
\hline Normal & o & \\
\hline $\begin{array}{l}\text { Missing operculum, and missing fins repeatedly, indicating possible } \\
\text { antagonist behaviours; darkening /inflammation of fin }\end{array}$ & 1 & \\
\hline $\begin{array}{l}\text { Mild scoliosis/ lordosis, tegument lesions, mucus production, over or } \\
\text { under conditioned (obese or thin), abrupt colour change, especially } \\
\text { blanching }\end{array}$ & 2 & \\
\hline $\begin{array}{l}\text { General emaciation (low body to head ratio), general body deformities, } \\
\text { missing or protuberant scales }\end{array}$ & 3 & \\
\hline \multicolumn{3}{|l|}{ Food consumption } \\
\hline Normal & 0 & \\
\hline Unresponsive to food during 1 day & 1 & \\
\hline Unresponsive to food during 2 days, not even live food & 2 & \\
\hline $\begin{array}{l}\text { Unresponsive to food more than } 3 \text { days not even live food as artemia or } \\
\text { rotifers (**) }\end{array}$ & 3 & \\
\hline \multicolumn{3}{|l|}{ Respiratory pattern } \\
\hline Normal & o & \\
\hline Piping or extremely low rate, almost no opercular movement & 3 & \\
\hline \multicolumn{3}{|l|}{ Swimming behaviour $(* *)$} \\
\hline Swimming through the water column & o & \\
\hline Difficulties to control buoyancy and/or to maintain equilibrium & 2 & \\
\hline Systematic swimming on the surface or in the bottom of the tank & 3 & \\
\hline \multicolumn{3}{|l|}{ Activity (**) } \\
\hline Normal & 0 & \\
\hline Hyperactive (erratic swimming) or hypoactive & 2 & \\
\hline Letargic, no reaction to external stimuli & 3 & \\
\hline \multicolumn{3}{|l|}{ Social behaviour $(* *)$} \\
\hline Normal. Shoaling. & o & \\
\hline Individual often isolated when group-housed & 1 & \\
\hline Individual always chasing or being chased by conspecifics & 2 & \\
\hline Individual does not respond to conspecific behaviours towards him & 3 & \\
\hline \multicolumn{3}{|l|}{ TOTAL } \\
\hline \multicolumn{3}{|c|}{$\begin{array}{l}\text { Judgement: 0-1 Normal; 2-8 Monitor carefully. Consider veterinary treatment including analgesics and consider } \\
\text { also to analyse water quality; 9-12 Suffering, provide relief, consult the specialized veterinarian, consider } \\
\text { euthanasia. } 13-18 \text { severe status, euthanasia, rethink experimental procedure. Euthanasia may be considered if a } \\
\text { score of } 3 \text { is observed in any of the categories, except for behaviour-related categories (**), in which scores of } 3 \\
\text { suggests repeated and close observation for a final decision regarding euthanasia. *Take in consideration animals' } \\
\text { age. }\end{array}$} \\
\hline
\end{tabular}




\section{CONCLUDING REMARKS}

The use of a suitable anaesthetic protocol able to produce anaesthesia with effective analgesia is an important refinement for painful procedures. Studies addressing the effects of anaesthetics in zebrafish are variable and lack important information such as the time during which the anaesthetic stage can be maintained without secondary effects, a clear description of the anaesthesia stage achieved with certain dose, and data about recovery. This lack of information can have a negative impact on zebrafish welfare when investigators are not familiarized with zebrafish anaesthesia. In addition, analgesia in zebrafish is another topic that needs further investigation to refine analgesic protocols during experimental procedures and for postoperative pain management, thus ensuring zebrafish welfare and reliable data collection.

In general, MS222 is a good anaesthetic, justifying its wide use in zebrafish19, but further refinement could be valuable when long duration procedures are required ${ }^{11,21}$. Furthermore, two studies described zebrafish aversion towards this anaesthetic ${ }^{22,36}$. Thus, finding other anaesthetic protocols are advisable, for example, the use of anaesthetic combinations to decrease individual concentrations and the risk of unwanted effects. Also, lidocaine seems to be the more promising analgesic to be used in zebrafish, however, its efficacy needs to be tested in different painful procedures and experimental situations.

\section{Acknowledgements}

The authors thank to Hugo Santos (BOGA, CIIMAR - Interdisciplinary Centre of Marine and Environmental Research), Ana Cristina Borges, Maysa Franco e Liliana Vale (IGC - Instituto Gulbenkian de Ciência), Petra Pintado e Fábio Valério (CEDOC - NOVA Medical School), and Sandra Martins (Champalimaud Foundation) for the critical comments on the scoring sheet table. This work was supported by the Post-Doctoral Fellowship SFRH/BPD/103006/2014 funded by FCT, and by the Fellowship BI/CITAB/UTAD/VET/2015 supported by: European Investment Funds by FEDER/COMPETE/POCI- Operacional Competitiveness and Internacionalization Programme, under Project POCl-01-0145-FEDER-006958 and National Funds by FCT - Portuguese Foundation for Science and Technology, under the project UID/AGR/04033/2013.

\section{REFERENCES}

1. Kalueff AV, Echevarria DJ and Stewart AM. Gaining translational momentum: more zebrafish models for neuroscience research. Prog Neuropsychopharmacol Biol Psychiatry. 2014; 55: 1-6.

2. Valentim AM, Felix LM, Carvalho L, Diniz E and Antunes LM. A New Anaesthetic Protocol for Adult Zebrafish (Danio rerio): Propofol Combined with Lidocaine. PLoS One. 2016; 11: e0147747. 
Neiffer DL and Stamper MA. Fish sedation, analgesia, anesthesia, and euthanasia: considerations, methods, and types of drugs. ILAR J. 2009; 50: 343-60.

4. Sneddon LU. Pain in aquatic animals. J Exp Biol. 2015; 218: 967-76.

5. Jones RC. Fish sentience and the precautionary principle. Animal Sentience: An Interdisciplinary Journal on Animal Feeling 2016; 1.3: 10.

6. Sneddon LU, Braithwaite VA and Gentle MJ. Do fishes have nociceptors? Evidence for the evolution of a vertebrate sensory system. Proc Biol Sci. 2003; 270: 1115-21.

7. Sneddon LU, Braithwaite VA and Gentle MJ. Novel object test: examining nociception and fear in the rainbow trout. J Pain. 2003; 4: 431-40.

8. Mettam JJ, Oulton LJ, McCrohan CR and Sneddon LU. The efficacy of three types of analgesic drugs in reducing pain in the rainbow trout, Oncorhynchus mykiss. Appl Anim Behav Sci. 2011; 133: 265-74.

9. Rose JD, Arlinghaus R, Cooke SJ, et al. Can fish really feel pain? Fish Fisheries 2014; 15: 97-133.

10. Iwama GK. The welfare of fish. Dis Aquat Organ. 2007; 75: 155-8.

11. Sneddon LU. Clinical Anesthesia and Analgesia in Fish. Journal of Exotic Pet Medicine 2012; $21: 32-43$.

12. Jevtovic-Todorovic $\mathrm{V}$, Absalom AR, Blomgren $\mathrm{K}$, et al. Anaesthetic neurotoxicity and neuroplasticity: an expert group report and statement based on the BJA Salzburg Seminar. Br J Anaesth. 2013; 111: 143-51.

13. Ferreira JT, Schoonbee HJ and Smit GL. The uptake of the anaesthetic benzocaine hydrochloride by the gills and the skin of three freshwater fish species. Journal of Fish Biology. 1984; 25: 35-41.

14. Carter KM, Woodley CM and Brown RS. A review of tricaine methanesulfonate for anesthesia of fish. Reviews in Fish Biology and Fisheries. 2011; 21: 51-9.

15. Ross LG and Ross B. Anaesthetic and Sedative Techniques for Aquatic Animals. Oxford, UK: Blackwell Publishing, 2008.

16. Nordgreen J, Tahamtani FM, Janczak AM and Horsberg TE. Behavioural effects of the commonly used fish anaesthetic tricaine methanesulfonate (MS-222) on zebrafish (Danio rerio) and its relevance for the acetic acid pain test. PLoS One. 2014; 9: eg2116.

17. Murray MJ. Fish surgery. Semin Avian Exot Pet Med. 2002; 11: 246-57.

18. Pereira N. Introduction to Anaesthesia and Surgery in Fish. In: Oliveira M, Bernardo F and Robalo Jl, (eds.). Practical Notions on Fish Health and Production. Sharjah: Bentham Science Publishers, 2016, p. 127-82.

19. Lidster K, Readman GD, Prescott MJ and Owen SF. International survey on the use of zebrafish in research. (Under submission). 
20. Collymore C, Tolwani A, Lieggi C and Rasmussen S. Efficacy and safety of 5 anesthetics in adult zebrafish (Danio rerio). J Am Assoc Lab Anim Sci. 2014; 53: 198-203.

21. Huang WC, Hsieh YS, Chen IH, et al. Combined use of MS-222 (tricaine) and isoflurane extends anesthesia time and minimizes cardiac rhythm side effects in adult zebrafish. Zebrafish. 2010; 7: $297-304$.

22. Readman GD, Owen SF, Murrell JC and Knowles TG. Do fish perceive anaesthetics as aversive? PLoS One. $2013 ;$ 8: e73773

23. Davis MW, Stephenson J and Noga EJ. The effect of tricaine on use of the fluorescein test for detecting skin and corneal ulcers in fish. J Aquat Anim Health. 2008; 20: 86-95.

24. Berstein PS, Digre KB and Creel DJ. Retinal toxicity associated with occupational exposure to the fish anesthetic MS-222. Amer J Ophthalmol 1997; 124: 843-4.

25. Medicine CfV. Concerns Related to the use of Clove Oil as an Anesthetic for Fish. Rockville 2007.

26. Schroeder P. Exploring suitable analgesics in zebrafish - a combined approach. 13th Felasa Congress. Brussels, Belgium. 2016, p. 32.

27. Steinbacher DM. Propofol: a sedative-hypnotic anesthetic agent for use in ambulatory procedures. Anesth Prog. 2001; 48: 66-71.

28. Gholipourkanani $\mathrm{H}$ and Ahadizadeh S. Use of propofol as an anesthetic and its efficacy on some hematological values of ornamental fish Carassius auratus. Springerplus. 2013; 2: 76.

29. Karmarkar SW, Bottum KM and Tischkau SA. Considerations for the use of anesthetics in neurotoxicity studies. Comp Med. 2010; 60: 256-62.

30. Kohrs R and Durieux ME. Ketamine: teaching an old drug new tricks. Anesth Analg. 1998; 87: 1186-93

31. Kanungo J, Cuevas E, Ali SF and Paule MG. Ketamine induces motor neuron toxicity and alters neurogenic and proneural gene expression in zebrafish. J Appl Toxicol. 2013; 33: 410-7.

32. Burgess HA and Granato M. Sensorimotor gating in larval zebrafish. J Neurosci. 2007; 27: 4984-94

33. Felix LM, Antunes LM and Coimbra AM. Ketamine NMDA receptor-independent toxicity during zebrafish (Danio rerio) embryonic development. Neurotoxicol Teratol. 2014; 41: 27-34.

34. Oliveira RF. Mind the fish: zebrafish as a model in cognitive social neuroscience. Front Neural Circuits. 2013; 7: 131 .

35. Grush J, Noakes DL and Moccia RD. The efficacy of clove oil as an anesthetic for the zebrafish, Danio rerio (Hamilton). Zebrafish. 2004; 1: 46-53.

36. Wong D, von Keyserlingk MA, Richards JG and Weary DM. Conditioned place avoidance of zebrafish (Danio rerio) to three chemicals used for euthanasia and anaesthesia. PLoS One. 2014; 9: e88030. 
37 .

Chambel J, Pinho R, Sousa R, et al. The efficacy of MS-222 as anaesthetic agent in four freshwater aquarium fish species. Aquaculture Research. 2015; 46: 1582-9.

38. Amend DF, Goven BA and Elliot DG. Etomidate: effective dosages for a new fish anesthetic. Trans Am Fish Soc. 1982; 111: 337-41.

39. Zakhary SM, Ayubcha D, Ansari F, et al. A behavioral and molecular analysis of ketamine in zebrafish. Synapse. 2011; 65: 160-7.

40. Maximino C. Modulation of nociceptive-like behavior in zebrafish (Danio rerio) by environmental stressors. Psychology \& Neuroscience. 2011; 4: 149-55.

41. Roques JA, Abbink W, Geurds F, van de Vis $\mathrm{H}$ and Flik G. Tailfin clipping, a painful procedure: Studies on Nile tilapia and common carp. Physiol Behav. 2010; 101: 533-40. 